\title{
EVALUATION OF THE PATIENTS' SATISFACTION WITH PSYCHIATRIC HEALTH CARE SERVICES WITH AN ADAPTED PIPEQ-OS TOOL
}

\author{
Natālija Bērziṇa-Novikova ${ }^{1, \#}$ and Māris Taube ${ }^{1,2}$ \\ ${ }^{1}$ Department of Psychiatry and Narcology, Rīga Stradiṇš University, 2 Tvaika Str., Rīga, LV-1005, LATVIA \\ ${ }^{2}$ Rīga Centre of Psychiatry and Narcology, Community Centre "Veldre", 1a Veldres Str., Rīga, LV-1064, LATVIA \\ \# Corresponding author, natalija.berzina-novikova@rsu.Iv
}

Communicated by Modra Murovska

\begin{abstract}
Until now, the assessment of health care services provided by psychiatric institutions in Latvia has not been carried out and questionnaires to provide assessment from the patient's perspective have not been adapted. For this study, a questionnaire that has been validated and successfully employed for several years in Norway was chosen to assess patients' experience and in a psychiatric inpatient setting. The aim of the study was to determine patients' satisfaction with the quality of mental health care services in Latvia in the subacute inpatient psychiatric ward in Riga, adapting during this process the PIPEQ-OS (Psychiatric Inpatient Patient Experience Questionnaire) tool in Latvia. The pilot quantitative study was conducted from June 2016 till February 2017. In the study, an anonymous patient self-assessment questionnaire PIPEQ-OS containing 21 questions was used. During the adaptation process, the questionnaire was translated from English into Latvian and Russian and backwards. The quality and compliance of the translation was subsequently tested in cognitive interviews. During the study, 297 patients were discharged from the unit, and 231 of them completed the questionnaire. 12\% of the completed questionnaires were not included in data processing due to being incorrectly filled in. Cognitive interviews with 20 patients were carried out; the average length of an interview was 15 minutes. Overall, the translation of the questionnaire proved to be relevant to the research theme. The subsequent factor analysis revealed three significant factors that reached the Cronbach's alpha index of 0.7. Further studies using socio-demographic data and based on various inpatient units as well as the comparison of satisfaction indicators across different diagnostic groups are needed.
\end{abstract}

Key words: assessment, quality of care, questionnaire, health care services.

\section{INTRODUCTION}

Every day mental health care professionals and psychiatrists face complex issues related to examination of patients with mental disorders, assessment of patient mental health condition, treatment, consideration and evaluation of various risk factors. How often, however, are patients being asked for their opinion on the received care? Patient's opinion and assessment, irrespective of whether it is a general inpatient hospital (Gleeson et al., 2016) or a psychiatric hospital ward, is of no less importance and value. There are studies reported in literature specifying health care areas in which patients are particularly attentive and demanding. For instance, in studies on determining the quality of care, pa- tients with somatic diseases most often noted the need for improvements specifically in the process of expecting health care interventions and availability of information (Gleeson et al., 2016). It is patients' opinion that points to the quality of care in the field of psychiatry (Epstein, 1996; Bleich et al., 2009), whereas high-quality care, in its turn, affects the frequency of post-discharge disease exacerbations and outcomes (Priebe et al., 2011). In 2018, the European Psychiatry Journal published a research study conducted by a group of scientists from the Netherlands on the correlation between the satisfaction of the received care and the outcomes of psychosis. The study demonstrated that higher satisfaction indicators predicted greater improvements in reduction in pscychotic symptoms during the first 
three years after hospitalisation (Vermeulen et al., 2018). Thus, prediction of outcome options allows professionals to choose different treatment and rehabilitation measures for the person to maximally integrate into society without being excluded. It increases and trains person's adaptive capacities, understanding of disease, ability to cope with it and to contribute to society as well as decreases stigmatisation - a global problem in psychiatry. It should be noted that according to the conclusions of a meta-analysis study published in the World Psychiatry Journal in 2017, the predominant belief in the society is that visiting a psychiatrist is better than going to a psychiatric hospital to receive help despite the fact that the negative public perception of psychiatry is diminishing. The authors of the study explained it by the lack of contact between the patient and the physician in psychiatric care (Angermeyer et al., 2017). When looking at the assessment of health care quality as such in more detail, we are confronted with the fact that this type of assessment has to be implemented in several phases; it consists of various elements, the first being implementation of a tool to measure patient satisfaction (Kilbourne et al., 2010). This is complicated by the fact that patient satisfaction may depend not only on the received care but also on the patient expectations with regard to care (Sofaer and Firminger, 2005). As clinical psychiatrists, we focus more on the treatment process and evaluation of outcomes, leaving structural assessment to health care providers. However, it is also important to show health care organisations and institutions that tools for assessing patients' opinion are applicable in practice in clinics (Riiskjær et al., 2010).

Effective health care strategies and standards comprise several aspects, one of which is provision of patient-oriented care (Pincus et al., 2007). During the past 20-30 years, according to the literature data, public perceptions towards the availability and search of psychiatric help are changing along with the changes taking place in physician-patient relationship model and public awareness of mental disorders (Angermeyer et al., 2017). Also, the number of studies attempting to analyse and determine the importance of patient satisfaction with regard to various disease aspects is increasing. Higher levels of patient satisfaction are linked to a greater chance of socially favourable outcomes in health care (Vermeulen et al., 2018) and higher quality of life also among psychiatric patients (Priebe et al., 2011; Zendjidjian et al., 2014). In addition, there is proven contribution of correct therapeutic relationship to positive self-assessment of patient satisfaction with care (Barbato et al., 2014; Zendjidjian et al., 2014), thus enhancing patient's motivation to seek help when needed (Awara and Fasey, 2008), providing the sense of security and support to patients and effective opportunity to influence the frequency of exacerbations, as higher level of satisfaction determines higher patients' compliance to treatment (Awara and Fasey, 2008; Zendjidjian et al., 2014). Patient satisfaction in general is linked to a number of various factors such as sociodemographic factors (Kuosmanen et al., 2006; Bleich et al., 2009), patient's mental condition, the particular nosological entity in psychiatry, treatment received, the frequency of hospitalisations (Woodward et al., 2017), and availability of information on the treatment process (Kuosmanen et al., 2006).

In the literature (Hansson et al., 1993), a number of aspects evaluated by the patients upon receiving care have been put forward, and the most relevant aspect, naturally, turned out to be the staff's emotional intelligence and attitude towards patients (Hansson et al., 1993; Schröder et al., 2006), whereas physical parameters of the hospital unit, the environment and interior were least important (Hansson et al., 1993). Even though research databases contain a wide variety of studies, data from studies are often contradictory with regard to the examined patient satisfaction factors (Woodward et al., 2017). There are studies on differences in satisfaction levels across various psychiatric diagnostic groups, as well as with regard to the side effects of pharmaceutical treatment (Gebhardt et al., 2013). The established differences in studies allows us to draw conclusions on an insufficient system of assessment, its specific characteristics depending on the state health care organisation and application of the tool (Kilbourne et al., 2010) and, just as importantly, the increasing involvement of health care providers in organisation of the health care quality assessment (Riiskjær et al., 2010). It provides insights into what questions should be included in the tools intended for patients to complete in order to clarify patients' opinion and assessment. In psychiatry, there are significant impediments to the development of assessment tools as questionnaires applied in general medicine cannot be used for patients with mental disorders (Boyer et al., 2009). Patient satisfaction assessment tools used in general medical practice are not suitable and appropriate to this patient group due to their differences in perception and various needs. Therefore, these tools cannot be used to obtain and present statistically and contentwise reliable data (Zendjidjian et al., 2014). Nevertheless, a few studies demonstrate that patients with severe mental health disorders are able to express their opinion with the help of a questionnaire if an appropriate tool is offered (Barbato et al., 2014).

Already in the middle of the last century, the world moved towards the implementation of a deinstitutionalisation process in the field of psychiatry with the aim of reducing the length of in-hospital stay and ensuring high-quality outpatient care. If the aim of the process is to improve the quality of mental health care, firstly, it is necessary to be aware of its current level in hospitals. According to the published data of a recent WHO research study (2016), an authentic and qualitative deinstitutionalisation process is characterised not only by progress towards the reduction of hospital beds but also by the compliance of the health care system operation and offered services with the needs of patients (Taylor Salisbury et al., 2016). This once again stresses the need for the assessment of quality in the health care field from the patient's perspective. The Ministry of Welfare of Latvia has prepared the Action Plan for 2014-2020 web page (Anonymous, 2018), with regard to the deinstitutionalisation process implemented in Latvia, which emphasises the need to develop qualitative, individually tailored health 
care services. The Ministry's of Health Agenda for 2016 states that it is planned to start the development and implementation of a unified quality assuarance system in the health care field which, in its turn, will further ensure high-quality, effective, safe and patient-oriented care.

The research theme was chosen based on the current problems in Latvia, addressing the need for adjusted tool for patient satisfaction measuring in psychiatric clinics. Recent deinstitutionalization process requires care quality assessment and improvement in different care settings (Anonymous, 2018) to provide continuing treatment for patients thus decreasing the disability, mortality and increasing the quality of life and compliance to treatment.

It is worth mentioning that, in accordance with the statistical metadata published by the Disease Prevention and Control Centre, the number of admitted patients with mental and behavioural disorders was 5810 patients in 2016 in absolute terms, which increased compared to the data of 2015 when the number of such patients was 5211 (Šica et al., 2017). Therefore, the chosen line of research will provide information on the patient satisfaction with the provided mental health care services and point to the possible lines of action, thus achieving improvement in the quality of mental health care services, which, according to the world's literature sources, has a scientifically proven role in the reduction of the frequency of rehospitalisation, achieving better disease outcomes and renewal of work capacity.

The PIPEQ-OS questionnaire, which was validated and successfully and conveniently used in Norway, was chosen. In this questionnaire, patients answer 21 questions and evaluate the quality of the offered mental health care (Bjertnaes et al., 2015).

By examining health care services from the patient's perspective, it is possible to develop programmes and guidelines for the improvement of quality in health care, in this way directing the country towards progressive action. Until now, there has been no research conducted in Latvia on the satisfaction of adult psychiatric patient population with the received care. This study can be considered unique in Latvia in this respect. The aim of the study was to determine patients' satisfaction with the quality of mental health care services using the PIPEQ-OS questionnaire in the subacute psychiatric inpatient ward in Riga, Latvia. One of the first tasks of this pilot study is to adapt the PIPEQ-OS tool in Latvia, to subsequently survey the patients on the quality of care and received services in the sub-acute inpatient ward of one of Latvia's psychiatric hospitals, and to examine patients' evaluation of the quality of provided services from various aspects. This would aid to determine directions for further research in this field.

\section{MATERIALS AND METHODS}

This type of assessment in subacute departments is considerably hampered by the nature of patients' mental health condition, and because contradictory information can be provided due to the disease course of patients. It was planned to initially survey the patients in a subacute ward. For this pilot study, the subacute ward of Riga Centre of Psychiatry and Narcology in Rìga, the capital of Latvia, was chosen. The PIPEQ-OS questionnaire was chosen on the basis of several criteria. The questionnaire has been validated in Norway for use specifically in an inpatient department. It includes 21 questions which can be answered quickly, thus increasing the chances of higher patient responsiveness. With this questionnaire, it is possible to assess several aspects of care at once, for example, personnel's interaction with the patient, and assessment of outcomes and conditions in the inpatient ward. The chosen questionnaire is not only relatively short but it also comprises questions characterising general psychiatric care such as the choice of food in the ward, and welcoming to the hospital, which are not always included in other patient satisfaction measurement tools (Gigantesco et al., 2003). According to research data, in selecting a tool for measuring patient satisfaction, preference should be given to a questionnaire that contains positively formulated questions. It is also advisable to use questionnaires containing Likert-type scale responses instead of closed-ended questions (Boyer et al., 2009), as well as to formulate questions so that respondents can provide assessment (Braun et al., 2012). Completion of the questionnaire in the ward increases response rates compared with sending questionnaires to patients following discharge (Boyer et al., 2009; Bjertnaes et al., 2015).

A cross-sectional study using an anonymous PIPEQ-OS questionnaire with 21 questions was conducted. Information on the background of the study and its goals is given in a generalized form in the beginning of the questionnaire. It is also explained that by completing the questionnaire and returning it, participation in the study is confirmed. In order to obtain maximally precise patient responses, the questionnaire did not contain questions requesting any sensitive information. During the process of questionnaire adaptation, with permission from the authors, the questionnaire was translated from English into Latvian and backwards. Translation was performed by two independent translators of the Language Centre of Rịga Stradiňš University. The same was done for the Russian version of the questionnaire. The compliance of the translation with the contents of the questionnaire questions was tested in cognitive interviews with 20 randomly selected patients. Patients came from different age groups, had different educational backgrounds and represented both genders. The average length of a cognitive interview was 15 minutes for each patient.

A further pilot study included patients hospitalised in the period from 1 June 2016 till 1 February 2017. Questionnaires were offered to all patients except patients with severe mental retardation and severe dementia. The questionnaire was offered to be filled in one day before the patient was discharged from the facility. The questionnaire was offered to the patient by the staff on duty. Upon offering the questionnaire, the aim of the survey, the principle of ensuring confidentiality was explained orally to the patient and 
the patient was asked to fill in the questionnaire alone in order not to affect individual survey results in any way. After completing the questionnaire, patients were asked to leave the questionnaire in specially designated closed boxes that were placed in the ward. Questionnaires were collected from the box once a week by the researcher who had no contact with the patients in the ward. Inaccurately completed questionnaires were excluded from further analysis - responses to the control question, which was formulated contrary to all the other questions in the questionnaire, were equivalent to the rating of other questions. It was followed by statistical analysis of data, using descriptive statistical data processing methods. Analysis of the tool's internal consistency reliability was performed using factor analysis - Cronbach's alpha indicator was determined for questionnaire questions separately and factors were identified as well as total correlation analysis of questions was performed.

\section{RESULTS}

From 1 June 2016 till 1 February 2017, 297 patients were discharged from the $20^{\text {th }}$ (subacute) inpatient ward of Riga Centre of Psychiatry and Narcology; questionnaries were offered to all the patients. The number of collected questionnaires was 231 . It shows that $78 \%$ of the hospitalised patients agreed to participate in the survey, which is a relatively high response rate for a self-reported questionnaire. Of all the collected questionnaires (231 questionnaires), $12 \%(\mathrm{n}=27)$ were not used in data processing based on exclusion criteria (i.e. questionnaires were completed incorrectly in relation to the control question, as well as there were some partially completed questionnaires). The other $204(88 \%)$ completed questionnaires were analysed further.
In the given period, 134 questionnaires in Latvian were completed and returned. During the practical application of the questionnaire in Latvian, the issue of the need to translate the questionnaire into Russian was raised in October of 2016. This situation is explained by the fact that Russians constituted $26.62 \%$ of Latvia's population in 2016, whereas in Riga, the capital of Latvia, Latvians constituted even less than a half of the population in 2016 (Anonymous, 2016). Thus, until 1 February 2017, 65 more questionnaires in Latvian and 32 questionnaires in Russian were collected. Analysis of the data loss in each question showed that altogether there were four questions with a large data loss (response was missing or N/A response was provided). Greatest loss of data was found in Question 5, which constituted $44.2 \%$ of all questionnaires included in the study. The question was formulated as follows: "Do you consider that the clinicians/personnel have cooperated well with your nextof-kin?" Data loss of 33\% was encountered also in the control question (Question 16). The control question was formulated as follows: "Do you believe that you have been subjected to malpractise during your stay (based on you own opinion)?" Question 6 with the data loss of $4.9 \%$ is also worth mentioning. This question concerned patient's opinion on whether the clinicians/personnel have prepared them well for the time after discharge? Question 9 with the data loss of $15.7 \%$ addressed the chance of a patient to influence the choice of their medications.

The assessment system of the questionnaire was composed of a rating scale from 1 to 5 or "N/A" (not applicable), where " 5 " denoted that a patient agreed with the question asked to the greatest extent, whereas " 1 " denoted that a patient agreed with the question asked regarding the patient's experience of receiving inpatient treatment to the least extent. In Figure 1, patient responses with the value of "5"

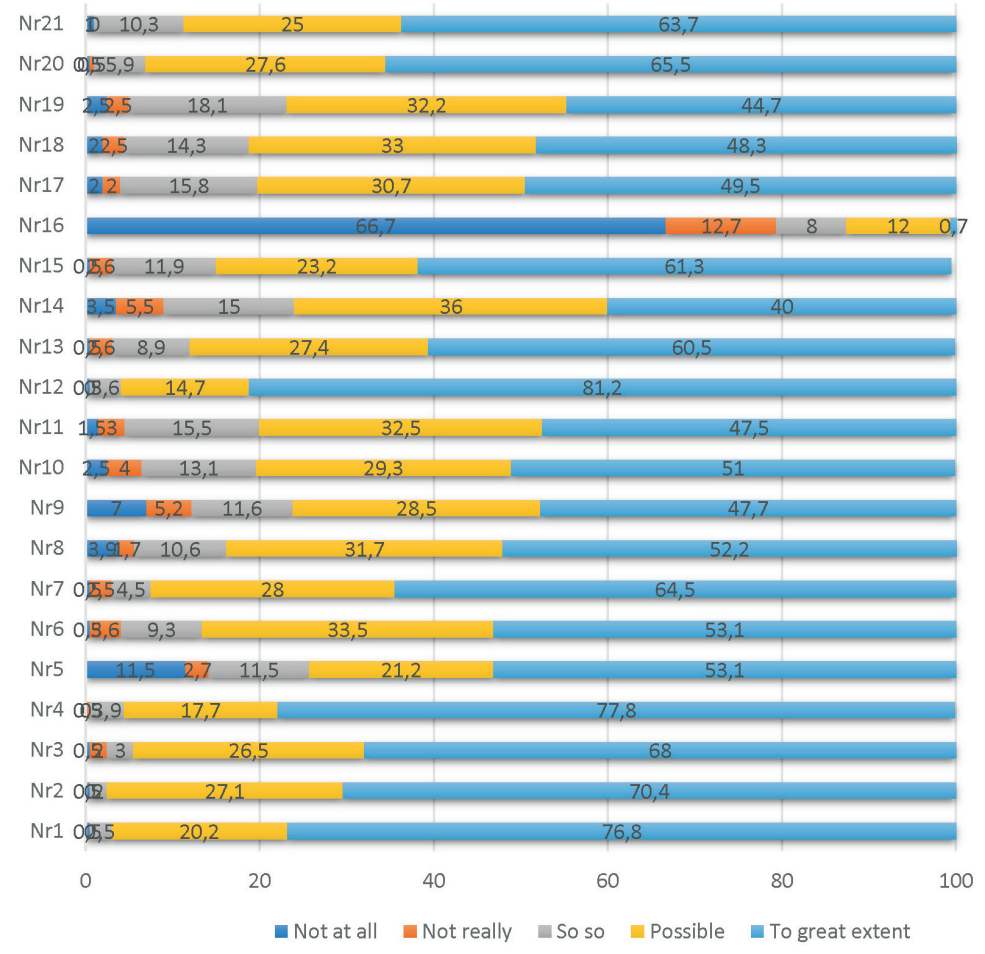

Proc. Latvian Acad. Sci., Section B, Vol. 73 (2019), No. 4.
Fig. 1. Patients' experience evaluation in PIPEQ-OS questionnaire. 
have been highlighted in light blue, which indicates that respondent's opinion corresponds with the statement included in the question to the greatest extent. The figure shows that of all the patients who completed the questionnaire, 100 patients responded to Question 16 by indicating "Not at all" or "1", which denotes that the respondent does not agree with the statement. The majority of respondents $(81.2 \%)$ answered Question 12 ("Have you felt safe at the institution?") in the affirmative. $76.8 \%$ of all the patients who completed the questionnaire confirmed that they were satisfied with the way they were welcomed when admitted to the ward. $77.8 \%$ admitted that they had a chance to discuss their health condition with personnel/clinicians. Table 1 shows that more than a half of patients noted that they had enough time for contact with medical personnel (Question 2) and that medical personnel understood the patient's situation (Question 3) and that medical personnel prepared patients well for the time after discharge (Question 6). Aspects such as the compliance of the received treatment with the patient's situation, possibility to influence the treatment regime and providing of sufficient information on patient's health condition were highly evaluated from the patient's perspective. More than $50 \%$ of patients highly evaluated offered activities and possibility for privacy.

As a result of factor analysis, factor loading pointed to the presence of four multivariate factors in the questionnaire. Accordingly, each factor with included items was analysed further. Subsequent factor analysis identified three relevant factors that met the Cronbach's alpha index of 0.7 , which is shown in Table 1. Interaction with the patient was the first factor to meet Cronbach's alpha value of 0.814 , the second factor, which comprised questions on the structure, environment and services of care, revealed a Cronbach's alpha value of 0.83 . Outcomes as the third factor reached a Cronbach's alpha value of 0.87 . Overall, questions in each factor were interrelated with certain exceptions. For example, Question 17 in the outcomes factor revealed lower total correlation, but further analysis showed that the value of Cronbach's alpha would decrease if the question was removed, which nevertheless reveals the correlation of this question in the overall context. Taking into account the need to ensure anonymity in the questionnaire, it was impossible to perform test-retest analysis, as there were no other patient data available. In the factor that included questions on interaction between the personnel and the patient, Question 8 revealed low total correlation with other factor questions. Also, removal of the question would improve internal consistency indicators for this factor. This question could be further isolated as a separate question in the questionnaire. The shown Cronbach's alpha values demonstrate positive total factor correlation in the questionnaire and compliance of the questions with the goal of the study, which permits the use of the questionnaire among the tested patients.

\section{DISCUSSION}

Completion of the questionnaires showed high response rate, which justifies effective application of the question-
Table 1

FACTOR ANALYSIS RESULTS WITH FACTOR LOADINGS

\begin{tabular}{|c|c|c|}
\hline Factor & $\begin{array}{l}\text { Factor } \\
\text { loading }\end{array}$ & $\begin{array}{c}\text { Cronbach's } \\
\text { alpha }\end{array}$ \\
\hline 1. Interaction with patient & & 0.81 \\
\hline $\begin{array}{l}\text { 3. Do you perceive that the clinicians/personnel } \\
\text { understand your situation? }\end{array}$ & 0.74 & \\
\hline $\begin{array}{l}\text { 4. Have you had the chance to tell the clinicians/ } \\
\text { personnel what is important about your } \\
\text { condition? }\end{array}$ & 0.62 & \\
\hline $\begin{array}{l}\text { 6. Do you consider that the clinicians/personnel } \\
\text { have prepared you for the time after discharge? }\end{array}$ & 0.67 & \\
\hline $\begin{array}{l}\text { 7. Do you consider that your treatment has been } \\
\text { adjusted to your situation? }\end{array}$ & 0.70 & \\
\hline $\begin{array}{l}\text { 8. Have you had influence on the choice of } \\
\text { treatment regime? }\end{array}$ & 0.40 & \\
\hline 2. Structure and facilities & & 0.83 \\
\hline $\begin{array}{l}\text { 2. Have you had enough time for talks and } \\
\text { contact with clinicians/personnel? }\end{array}$ & 0.56 & \\
\hline $\begin{array}{l}\text { 5. Do you consider that the clinicians/personnel } \\
\text { have cooperated well with your next-of-kin? }\end{array}$ & 0.45 & \\
\hline $\begin{array}{l}\text { 10. Has the institution given you adequate } \\
\text { information about your mental condition/ } \\
\text { diagnosis? }\end{array}$ & 0.69 & \\
\hline $\begin{array}{l}\text { 11. Has the institution given you adequate } \\
\text { information about the treatment options } \\
\text { available to you? }\end{array}$ & 0.59 & \\
\hline $\begin{array}{l}\text { 13. Have the activities offered at the institution } \\
\text { been satisfactory? }\end{array}$ & 0.59 & \\
\hline $\begin{array}{l}\text { 15. Have you been satisfied with the possibility } \\
\text { for privacy? }\end{array}$ & 0.59 & \\
\hline $\begin{array}{l}\text { 14. Were you welcomed satisfactorily when } \\
\text { admitted to the institution? }\end{array}$ & 0.33 & \\
\hline 12. Have you felt safe at the institution? & 0.47 & \\
\hline 3. Outcomes & & 0.87 \\
\hline $\begin{array}{l}\text { 17. Have the help and treatment you have } \\
\text { received at the institution improved your ability } \\
\text { to understand your mental condition? }\end{array}$ & 0.67 & \\
\hline $\begin{array}{l}\text { 18. Have the help and treatment you have } \\
\text { received at the institution improved your ability } \\
\text { to cope with your mental condition? }\end{array}$ & 0.79 & \\
\hline $\begin{array}{l}\text { 19. Have the help and treatment you have } \\
\text { received at the institution led you to believe that } \\
\text { your life will improve after discharge? }\end{array}$ & 0.69 & \\
\hline $\begin{array}{l}\text { 20. All in all, have the help and treatment you } \\
\text { have received so far at the institution been } \\
\text { satisfactory? }\end{array}$ & 0.71 & \\
\hline $\begin{array}{l}\text { 21. All in all, what benefit have you gained } \\
\text { from the treatment you have received so far at } \\
\text { the institution? }\end{array}$ & 0.70 & \\
\hline
\end{tabular}

naire, particularly in inpatient settings. Significant data loss was observed in the question on involvement of patient's next-of-kin in the treatment process, which is a significant finding during the study. These indicators could mean that patients did not have a chance to involve their relatives or it was not sufficiently discussed from the side of the medical personnel in the ward. Also, this could be associated with 
the fact that involvement of relatives in the treatment and support system is not relevant in patients' opinion. It follows from the research design that patients' mental condition could influence their responses in relation to the involvement of relatives in the treatment; however, this influence was minimised by the fact that questionnaires were offered to be filled in on a day before the discharge date when the mental health condition should have been compensated.

Lower response rates, which were observed in questions on the chance to influence the treatment process and the choice of medications, point to the still existing outdated physician-patient relashionship model on which patients and their relatives should be educated. These results could be indicative of insufficient patient awareness of the treatment process in general and the need for education. This aspect is especially important in psychiatric patient care as a safe, trustful physician-patient relationship and joint decision process improve patient's understanding of the disease and treatment thus increasing patient's compliance with the treatment in the future. It marks a direction in which inpatient care can be improved with regard to strengthening and facilitation of the physician-patient relationship. Lower satisfaction rates were observed in questions on the chance to influence the choice of medications as well as in relation to the availability of information, particularly on the types of treatment. Lower level of patient satisfaction was found in questions on the impact of treatment and support on positive assessment of future prospects with regard to their disease.

The results of the study demonstrate that there exists certain discrepancy between the patient's expectations of the received care and its organisation, which outlines aspects of further improvements.

During the process of questionnaire analysis, it was established that, in terms of content, the translation of the questions has been performed accurately. Some patients demonstrated lack of understanding with regard to their chances to influence the treatment process; however, this was not connected with the problem of translation but rather the concept as such, which was also revealed by the results of data analysis. There were also patients who believed that questions were too similar to be singled out separately. Others noted difficulties in completing the questionnaires due to translation of a few words; however, the essence of questions was understood. Overall, the translation of the questionnaire was understandable in terms of content and consistent with the theme of research; conceptual equivalence was observed. According to the results of cognitive interviews, minor adjustments to the questionnaires in both languages were applied. Overall, the translated questionnaires appeared relevant and relatively easy to fill in for the investigational patient group. The average length of time spent per questionnaire was 5-10 minutes, which is also a factor contributing to the high response rates.
As a result of factor analysis, total correlation of questions or questionnaire items demonstrated the strength of association of separate questions with the rest of questionnaire questions. Whereas, compliance with Cronbach's alpha in each factor revealed the general correlation between the factors identified among the items.

Comparing our results to the results of the PIPEQ-OS validation study (Bjertnaes et al., 2015) conducted in Norway in 2014 there are some similarities. Norwegian study had $74.6 \%$ response rate which is also in the acceptable range for such types of studies. Similar to the Bjetnaes et al. (2015) we found noticeable data loss in the question of involvement of the next-of-kin $(44.0 \%$ in our study and $36.9 \%$ in the study mentioned above) (Bjertnaes et al., 2015). We also came across some differences in levels of missing, for example, Norwegian colleagues in their paper describe $>20 \%$ missing in the questions about the medication choice and discharge. Our study also has some levels of data missing in those questions, but it is $<20 \%$. Further comparison of our study is impossible due to differences in the methodological approach and study design.

\section{LIMITATIONS}

Since it was a pilot study with the aim to highlight directions for further in-depth investigation and was conducted for the purpose of questionnaire adaptation in order to obtain maximally non-compromised responses, it was anonymous. No information about the patient was requested, which is also one of the greatest limitations of the study. It is therefore not possible to analyse the group of patients who refused to complete the questionnaire as well as to obtain socio-demographic data on patients, which creates some uncertainty as to the generalisation of the data. Since part of the study is descriptive, it is also not possible to draw conclusions on the correlation of factors with other patient and care-related factors. Higher positive care assessments are common in studies conducted in inpatient settings and using self-reported questionnaires compared to questionnaries mailed by post after discharge, and therefore further research on this issue is needed.

\section{CONCLUSIONS}

Patient responses to questions demonstrated that patients in general were satisfied with the services provided in the subacute psychiatric hospital. The low patient response rates in Question 5 allow concluding that there exist certain problems in the relationship between the patient and nextof-kin with the lack of understanding about the involvement of relatives in the treatment process. It may also point to the effect of stigmatisation in this respect. Further research on this issue is needed. However, the overall trend points to the fact that patients are willing to engage in their treatment process and be active, they are ready to cooperate and medical staff is forthcoming and supportive. 
The translated questionnaires appeared relevant for the investigated patient population and considerably easily to complete. This questionnaire was used in the study with permission of its developers who were interested in the results, which, in its turn, contributed to the strengthening of international cooperation with the neighbouring countries, giving rise to ideas for further international projects. By examining the provided health care services from the patient's perspective, it is possible to develop programmes and guidelines for improving the quality of care this way directing the country towards progressive action.

There is a need for studies that determine patient satisfaction indicators in specific diagnostic groups and their correlation with hospitalisation frequency, frequency of outpatient visits with possibilities to influence further treatment of patients, thus relieving pressure on social costs and treatment costs in perspective.

\section{REFERENCES}

Angermeyer, M. C., Auwera, S., van der, Carta, M. G., Schomerus, G. (2017). Public attitudes towards psychiatry and psychiatric treatment at the beginning of the $21^{\text {st }}$ century: A systematic review and meta-analysis of population surveys. World Psychiatry, 16 (1), 50-61.

Anonymous (2014). Latvian National Development Plan for 2014-2020. Available from: https://www.pkc.gov.lv/sites/default/files/images-legacy/ NAP2020\%20dokumenti/NDP2020_English_Final.pdf (accessed 15.05.2019)

Anonymous (2018). Eiropas Savienības struktūrfondi veselības nozarē [European Union Structural Funds in Health Care]. Available from: http://esfondi.vm.gov.lv/lat/2014_2020gads/ (accessed 12.12.2018).

Awara, M., Fasey, C. (2008). Patients' satisfaction and quality of care in psychiatric out-patient settings. J. Mental Health, 17 (3), 327-335.

Barbato, A., Bajoni, A., Rapisarda, F., D'Anza, V., De Luca, L. F., Inglese, C., Iapichino, S., Mauriello, F., D'Avanzo, B. (2014). Quality assessment of mental health care by people with severe mental disorders: A participatory research project. Commun. Mental Health J., 50 (4), 402-408.

Bjertnaes, O., Iversen, H. H., Kjollesdal, J. (2015) PIPEQ-OS — an instrument for on-site measurements of the experiences of inpatients at psychiatric institutions. BMC Psychiatry, 15 (1), 234.

Bleich, S. N., Ozaltin, E., Murray, C. K. L. (2009). How does satisfaction with the health-care system relate to patient experience? Bull. World Health Org., 87 (4), 271-278

Boyer, L., Baumstarck-Barrau, K., Cano, N., Zendjidjian, X., Belzeaux, R., Limousin, S., Magalon, D., Samuelian, J. C., Lancon, C., Auquier, P. (2009). Assessment of psychiatric inpatient satisfaction: A systematic review of self-reported instruments. Eur. Psychiatry, 24 (8), 540-549.

Braun, E. , Woodley, A., Richardson, J. T. E., Leidner, B. (2012). Self-rated competences questionnaires from a design perspective. Educ. Res. Rev., 7 (1), 1-18.

Epstein, K. R. (1996). Patients' perceptions of office medical practice: Judging quality through the patients' eyes. Amer. J. Med. Quality, 11 (2), 73-80.

Gebhardt, S., Wolak, A. M., Huber, M. T. (2013). Patient satisfaction and clinical parameters in psychiatric inpatients: The prevailing role of symp- tom severity and pharmacologic disturbances. Compreh. Psychiatry., 54 (1), 53-60

Gigantesco, A., Morosini, P., Bazzoni, A. (2003). Quality of psychiatric care: Validation of an instrument for measuring inpatient opinion. Int. J. Qual. Health Care, 15 (1), 73-78.

Gleeson, H., Calderon, A., Swami, V., Deighton, J., Wolpert, M., EdbrookeChilds, J. (2016). Systematic review of approaches to using patient experience data for quality improvement in healthcare settings. BMJ Open, 6 (8), $\mathrm{e} 011907$.

Hansson, L., Björkman, T., Berglund, I. (1993). What is important in psychiatric inpatient care? Quality of care from the patient's perspective. Qual. Assur. Health Care, 5 (1), 41-47.

Kilbourne, A. M., Keyser, D., Pincus, H. A. (2010). Challenges and opportunities in measuring the quality of mental health care. Can. J. Psychiatry, $\mathbf{5 5}$ (9), 549-557.

Kuosmanen, L., Hätönen, H., Jyrkinen, A. R., Katajisto, J., Välimäki, M. (2006). Patient satisfaction with psychiatric inpatient care. J. Adv. Nursing, 55 (6), 655-663.

Pincus, H. A., Page, A. E., Druss, B., Appelbaum, P. S., Gottlieb, G., England, M. J. (2007). Can psychiatry cross the quality chasm? Improving the quality of health care for mental and substance use conditions. Amer. J. Psychiatry, 164 (5), 712-719.

Priebe, S., Katsakou, C., Yeeles, K., Amos, T., Morriss, R., Wang, D., Wykes, T. (2011). Predictors of clinical and social outcomes following involuntary hospital admission: A prospective observational study. Eur. Arch. Psyciatry Clin. Neurosci., 261 (5), 377-386.

Riiskjaer, E., Ammentorp, J., Nielsen, J. F., Kofoed, P. E. (2010). Patient surveys - A key to organizational change? Patient Educ. Counseling, 78 (3), 394-401.

Schröder, A., Ahlström, G.,Larsson, B. W. (2006). Patients' perceptions of the concept of the quality of care in the psychiatric setting: A phenomenographic study. J. Clin. Nursing, 15 (1), 93-102.

Šica, K., Pulmanis, T.,Taube, M. (2017). Psihiskā veselība Latvijā 2016. gadā [Psychic health in Latvia in 2016]. Available from: https://www.spkc.gov.lv/upload/ Psihiska_veseliba_faili/tz_pvl_2016_final.pdf (accessed 15.05.2019).

Sofaer, S., Firminger, K. (2005). Patient perceptions of the quality of health services. Annu. Rev., Publ. Health, 26, 513-559.

Taylor Salisbury, T., Killaspy, H., King, M. (2016). An international comparison of the deinstitutionalisation of mental health care: Development and findings of the Mental Health Services Deinstitutionalisation Measure (MENDit). BMC Psychiatry, 16 (1), 1-11.

Vermeulen, J. M., Schirmbeck, N. F., van Tricht, M. J., de Haan, L.; Genetic Risk and Outcome of Psychosis (GROUP) investigators (2018). Satisfaction of psychotic patients with care and its value to predict outcomes. Eur. Psychiatry, 47, 60-66.

Woodward, S., Berry, K., Bucci, S. (2017). A systematic review of factors associated with service user satisfaction with psychiatric inpatient services. J. Psychiatric Res., 92, 81-93.

Zendjidjian, X. Y., Baumstarck, K., Auquier, P., Loundou, A., Lanēon, C., Boyer, L. (2014). Satisfaction of hospitalized psychiatry patients: Why should clinicians care? Patient Prefer. Adher., 8, 575-583.

Zendjidjian, X. Y., Auquier, P., Lanēon, C., Loundou, A., Parola, N., Faugčre, M., Boyer, L. (2014). Determinants of patient satisfaction with hospital health care in psychiatry: Results based on the SATISPSY-22 questionnaire. Patient Prefer. Adher., 8, 1457-1464. 

ADAPTĀCIJU

Latvijā līdz šim nav veikta psihiatrisko institūciju sniegto veselības aprūpes pakalpojumu izvērtēšana un nav adaptētas anketas, lai to novērtētu no pacientu skatu punkta. Pētījumam izvēejējāmies Norvēéijā jau vairākus gadus veiksmīgi izmantotu un validētu anketu pacientu pieredzes un apmierinātības novērtēšanai psihiatriskā profila stacionārā. Darba mērḳis bija noteikt pacientu apmierinātību ar psihiskās veselības sistēmas aprūpes kvalitāti Latvijā subakūtajā psihiatriskajā stacionārā Rīgā, procesā adaptējot PIPEQ-OS (Psychiatric Inpatient Patient Experience Questionnaire) anketu Latvijā. Pilotpētījums veikts no 2016. g. jūnija līdz 2017. g. februārim, tas ir kvantitatīvais pētījums. Pētījumā izmantota anonīma pašnovērtēšanas anketa pacientiem — PIPEQ-OS ar 21 jautājumu. Anketas adaptācijas procesā tā tika tulkota no angḷu valodas latviešu un krievu valodā un atpakal, ar kognitīvo interviju palīdzību testēta tulkojuma kvalitāte un atbilstība. Pētījuma laikā no nodaḷas izrakstījušies 297 pacienti, no tiem 231 ir aizpildījuši anketas. No tām 12\% netika iekḷauti datu apstrādē nekorekti aizpildīto anketu dēḷ. Kognitīvās intervijas veiktas ar 16 pacientiem, vidējais intervijas laiks 15 minūtes. Vairāki pacienti parādījuši neizpratni attiecībā uz jautājumiem par iespējām ietekmēt savu ārstēšanas procesu. Kopumā anketas tulkojums izrādījās atbilstošs pētījuma tēmai. Sekojoša faktoru analīze uzrādīja trīs nozīmīgus faktorus, kuri sasniedza Kronbaha alfa 0,7 indeksu. Nepieciešami turpmāki pētījumi ar sociāli demogrāfiskiem datiem dažādās stacionārā tipa nodạ̦ās, kā arī apmierinātības rādītāju salīdzināšana vairākās diagnožu grupās. 